\title{
Rевевсн автісів: Effect of seed treatments and storage containers on seed health and seed discolouration of popular rice (Oryza sativa L.) cultivars
}

\section{口 HARSHA, B. RAJESWARI, D. KRISHNAVENI AND A. CHIRANJEEVI}

Article Chronicle: Received : 15.07.2017;

Accepted : 30.07.2017

KEY WORDS:

Seed treatment, Seed discolouration, Polythene bag, Gunny bag, RNR 15048, JGL 18047

Author for correspondence :

\section{HARSHA}

Department of Plant Pathology, College of Agriculture,

Rajendranagar,

HYDERABAD

(TELANGANA) INDIA

See end of the article for authors' affiliations
SUMMARY : Two rice varieties viz., RNR 15048 (Telanganasona) and JGL 18047 (Bathukamma) were treated with three fungicides viz., thiram @ 0.3\%, carbendazim@0.2\% and mancozeb@0.25\% and three biocontrol agents viz., T. harzianum, T. viride and P. flourescence and stored in gunny bag and polythene bag were assessed for seed health and seed discolourationat biomonthlyintervals.In rice cv. RNR 15048, seeds treated with thiram and stored in polythene bag recorded lesser number of fungal colonies $(6.7 \%)$ and less seed discolouration $(22.5 \%)$ at the end of eight months storage period as against the seeds stored in gunny bag which recorded more number of fungal colonies $(8.25 \%)$ and high seed discolouration of $26 \%$, respectively.In rice cv. JGL 18047, seeds treated with thiram and stored in polythene bag recorded lesser number of fungal colonies $(6.5 \%)$ and less discolouration percentage $(23.5 \%)$ at the end of eight months storage period as against the seeds stored in gunny bag which recorded more fungal colonies $(9.5 \%)$ and seed discolouration percentage of $24 \%$, respectively. The other seed treatments viz., carbendazim, $P$. fluorescence, $T$. harzianum and T. viride were also found effective in reduction of seed mycoflora and seed discolouration as compared with untreated seeds of two rice cultivars in polythene bag storage.

How to cite this article : Harsha, Rajeswari, B., Krishnaveni, D. and Chiranjeevi, A. (2017). Effect of seed treatments and storage containers on seed health and seed discolouration of popular rice (Oryza sativa $\mathrm{L}$.) cultivars. Agric. Update, 12(TECHSEAR-5) : 1308-1312; DOI: 10.15740/HAS/AU/12.TECHSEAR(5)2017/ 1308-1312. 